\title{
Pohjaveden korkeuden vaikutus happaman sulfaattimaan ominaisuuksiin ja maan huokosveden koostumukseen
}

\author{
Seija Virtanen ja Asko Simojoki \\ Elintarvike- ja ympäristötieteen laitos, Helsingin yliopisto, Latokartanonkaari 11, 00014 Helsingin \\ yliopisto, seija.virtanen@helsinki.fi
}

\section{Tiivistelmä}

Happamilta sulfaattimailta purkautuva valumavesi on hapanta ja se sisältää haitallisen korkeita alumiinija raskasmetallipitoisuuksia. Nämä valumavedet ovat huonontaneet purkuvesistöjensä veden laatua. Veden happamuuteen ovat syynä maassa olevien sulfidien hapettumisessa vapautuvat protonit. Runsas protonien määrä edistää mineraalien rapautumista ja vapauttaa niissä olevia metalleja, jotka happamissa oloissa pysyvät liukoisina ja huuhtoutuvat vesistöön. Eräs ratkaisu valumaveden laadun parantamiseen on estää sulfidien hapettuminen pitämällä niitä sisältävät maakerrokset pohjaveden pinnan alla.

Pohjaveden korkeuden vaikutusta happamien sulfaattimaiden huokosveden laatuun tutkitaan Helsingin yliopistossa kesällä 2008 aloitetussa vuoden 2010 loppuun kestävässä lysimetrikokeessa. Kokeessa selvitetään maan kyllästymisen aiheuttamia muutoksia happamalta sulfaattimaalta otettujen maamonoliittien eri kerroksissa. Kokeessa pohjavettä pidetään joko korkealla (pohjavesi $20 \mathrm{~cm}$ syvyydellä) tai matalalla (pohjavesi $65 \mathrm{~cm}$ syvyydellä). Matalalla pohjavedellä simuloidaan normaalia kuivatusta ja korkealla pohjavedellä keinotekoisesti lähelle maan pintaa nostettua pohjavettä. Kymmenestä lysimetristä kahdeksassa kasvatetaan kosteita oloja sietävää ruokohelpiä ja kaksi on kasvitonta.

Kokeen ensimmäisenä vuonna korkea pohjavesi vähensi kasvillisen maan happamuutta horisonteissa B ja BC, kun veden alle joutuneet kerrokset pelkistyivät. Kun pohjavesi pidettiin matalalla, nämä kerrokset pysyivät hapettuneina. Veden kyllästämien kerrosten huokosveden alumiinipitoisuudet olivat alle kymmenesosa hapettuneiden kerrosten pitoisuuksista. Kun pohjavesi oli korkealla, raskasmetallien (Ni-, Co- ja Zn) pitoisuudet BC-kerroksessa olivat pienempiä kuin pohjaveden ollessa matalalla. Matalan pohjaveden koejäsenessä huokosveden alumiinipitoisuudet $\left(150 \mathrm{mg} \mathrm{l}^{-1}\right)$ ja Ni-, Co- ja Zn-pitoisuudet olivat yli viisinkertaisia salaoja- tai jokivesissä mitattuihin pitoisuuksiin verrattuna.

Korkean pohjaveden aiheuttaman pelkistymisen seurauksena huokosveden raudan pitoisuudet kohosivat B-kerroksessa suuriksi $\left(450 \mathrm{mg} \mathrm{l}^{-1}\right)$. Vastaavaa raudan määrän lisääntymistä huokosvedessä ei todettu kasvittomissa lysimetreissä. Syynä kasvillisen maan huokosveden suuriin rautapitoisuuksiin olivat todennäköisesti ruokohelven juuriston huokosveteen tuottamat orgaaniset hiiliyhdisteet, jotka toimivat rautaa pelkistävien mikrobien substraattina ja muodostivat liuenneen raudan kanssa orgaanisia yhdisteitä. Kokeen tulosten perusteella laskettiin huokosveden orgaanisten rautayhdisteiden osuudeksi yli puolet huokosveden kokonaisraudasta tässä kerroksessa.

Asiasanat: hapan sulfaattimaa, lysimetri, huokosvesi, veden laatu, ruokohelpi 


\section{Johdanto}

Happamien sulfaattimaiden valumavedet ovat huonontaneet purkuvesistöjensä veden laatua happamuutensa ja sisältämiensä myrkyllisen korkeiden metallipitoisuuksiensa vuoksi (Rautio 2008, Österholm \& Åström 2004). Happaman sulfaattimaan maaprofiili koostuu hyvin happamista maakerroksista, joiden alla on pelkistyneitä rikkiyhdisteitä sisältävä lähes neutraali maakerros. Sulfidit pysyvät pelkistyneinä pohjaveden pinnan alapuolella anaerobeissa oloissa. Kun pohjavesi laskee, happea pääsee maahan ja sulfidien hapettuminen alkaa. Myös ajoittain pohjaveden yläpuolella oleva maa voi muuttua happamaksi, koska hapen käynnistämä sulfidien hapettuminen voi jatkua anaerobeissa oloissa. Tällöin rautasulfideista vapautunut kolmenarvoinen rauta voi toimia hapettimena, jos maan $\mathrm{pH}$-arvo on alle 4 (Kirk 2004). Eräs keino valumaveden laadun parantamiseksi on pohjaveden pinnan pitäminen niin korkealla, että pelkistyneet kerrokset ovat aina veden kyllästämiä, niin etteivät ne pääse hapettumaan. Pohjaveden pintaa keinotekoisesti nostettaessa myös hapettuneita kerroksia joutuu veden alle. Veden alla ne alkavat pelkistyä. Pelkistyminen nostaa maan $\mathrm{pH}$-arvoa, muuttaa huokosvedessä olevien aineiden liukoisuutta ja vaikuttaa maan vaihtuvien ionien sitoutumispaikkojen määrään.

Pohjaveden korkeuden vaikutusta maan kemiallisiin ominaisuuksiin ja huokosveden koostumukseen happaman sulfaattimaan eri kerroksissa on tutkittu vuonna 2007 Helsingin yliopistossa aloitetussa tutkimushankkeessa. Lysimetrikoe kahdella eri pohjaveden korkeudella aloitettiin kesällä 2008 ja se jatkuu vuoden 2010 loppuun. Lysimetreissä kasvatetaan kosteita kasvuoloja sietävää ruokohelpeä, ja osa lysimetreistä on kasvittomia. Tavoitteena on selvittää pohjaveden korkeuden nostamisen vaikutus eri kerrosten hapetus-pelkistystilaan ja huokosveden koostumukseen. Hypoteesina on, että pohjaveden korkeutta nostamalla huokosveden happamuus ja metallien haitallisen korkeat pitoisuudet vähenevät. Tässä esitellään kokeesta saatuja ensimmäisen koevuoden tuloksia.

\section{Materiaalit ja menetelmät}

Maa lysimetreihin otettiin häiriintymättöminä maamonoliitteina Helsingin yliopiston Viikin koetilan pellolta, joka on hapanta sulfaattimaata (Sulphic Cryaquaept) (Yli-Halla, 2008). Pellon pinta on meren pinnan tasolla, ja se on pengerryskuivattu viljelyä varten 1950-luvulla. Pelto on salaojitettu tiiliputkilla keskimäärin metrin syvyyteen. Ojaväli on 14 - 60 m. Muokkauskerroksen alla oleva B-kerros on hapanta aktiivista sulfaattimaata. Hapettuneen ja pelkistyneen maan välillä oleva vaihtumiskerros (BC) sijoittuu suunnilleen salaojien syvyyteen, ja pelkistynyt sulfideja sisältävä maakerros (C) alkaa tämän alapuolelta. Maamonoliitit otettiin siten, että niiden alimmainen $20 \mathrm{~cm}: n$ kerros on C-horisontin maata, keskellä on 30 $\mathrm{cm}$ vaihtumiskerroksen maata ja muokkauskerroksen alla on hapettunutta B-kerroksen maata (taulukko 1).

Taulukko 1. Lysimetrin maakerrokset, niitä vastaavat horisontit pellolla, ja maasta määritettyjä ominaisuuksia.

\begin{tabular}{lccccccc}
\hline $\begin{array}{l}\text { Horisontti } \\
\text { pellolla }\end{array}$ & $\begin{array}{c}\text { Syvyys } \\
\text { Lysimetrissä } \\
(\mathrm{cm})\end{array}$ & $\mathrm{pH}$ & Saves & \multicolumn{2}{c}{$\mathrm{S}_{\text {tot }}$} & \multicolumn{2}{c}{ Oksalaattiuuttoiset } \\
$\mathrm{Al}$ & & $(\%)$ & $(\mathrm{g} / \mathrm{kg})$ & $(\mathrm{g} / \mathrm{kg})$ & Hiili \\
& $0-20$ & 6.4 & 33 & 0.4 & 1.6 & 4.7 & $(\%)$ \\
\hline $\mathrm{Ap}^{*}$ & $20-25$ & 5.0 & 32 & 0.9 & 4.4 & 10.5 & 1.7 \\
$\mathrm{~B} 1$ & $25-50$ & 3.8 & 61 & 4.2 & 4.1 & 13.2 & 1.9 \\
$\mathrm{Bgjc}$ & $50-80$ & 4.2 & 57 & 4.6 & 2.5 & 11.7 & 2.5 \\
$\mathrm{BCgc}$ & $80-100$ & 6.5 & 59 & 14.9 & 1.7 & 2.2 & 2.8 \\
$\mathrm{C}$ & & & & & & \\
\hline
\end{tabular}

* Muokkauskerroksen maa on ruokohelpeä kasvaneelta pellolta.

Häiriintymättömät maamonoliitit otettiin pellolta PVC -putkiin (halkaisija $0,5 \mathrm{~m}$, korkeus $1 \mathrm{~m}$, seinämäpaksuus $14,5 \mathrm{~mm}$ ) tätä tarkoitusta varten kehitetyn tekniikan avulla. Maamonoliitit otettiin niin että ylin $20 \mathrm{~cm}$ PVC -putkesta jäi tyhjäksi. Kaikkien monoliittien pinta tasattiin $25 \mathrm{~cm}$ syvyyteen ja täytettiin pellolta otetulla B1 kerroksen maalla niin, että $20 \mathrm{~cm}$ putkesta jäi tyhjäksi. Kahdeksaan lysimetriin istutettiin ylimmäksi kerrokseksi edellisvuonna kylvettyä ruokohelpikasvustoa. Kasvusto otettiin $15 \mathrm{~cm}$ maakerroksena PVC -putkiin (halkaisija 0,5 m) yhtenäisinä siirrännäisinä. Kaksi kasvitonta lysimetriä täytettiin seulotulla $(\varnothing 1 \mathrm{~cm})$ muokkauskerroksen maalla samaan korkeuteen. 
Lysimetrit kuljetettiin yliopiston kasvihuoneiden yhteydessä olevaan verkkohalliin, joka on katettu verkkoseinillä rajattu ulkoilmatila. Lysimetrit sijoitettiin niitä varten rakennetulle tasaiselle eristetylle alustalle ja jokaiseen lysimetriin liitettiin oma vedensäätöjärjestelmä, pohjavesiputket ja mittausanturit ennalta tehtyihin läpivienteihin. Sääolot pyrittiin järjestämään pellon oloja vastaaviksi, ja siksi lysimetrit eristettiin pintakerrosta lukuun ottamatta talveksi. Kasvusto ja pintakerros olivat alttiina ulkoilmalle, mutta eristyksen sisällä olevat maakerrokset pidettiin keskimäärin $+5{ }^{\circ} \mathrm{C}$ lämpötilassa termostaatilla säädettyjen lämpöpuhaltimien avulla. Kesällä eristys muutettiin aurinkosuojaksi maan sisäisten lämpötilaerojen tasaamiseksi.

Pohjaveden korkeuden vaikutusta happaman sulfaattimaan ominaisuuksiin ja huokosveden koostumukseen tutkittiin kahdella eri pohjaveden korkeudella, 20 ja $65 \mathrm{~cm}$ maan pinnan alapuolella. Korkean vedenpinnan käsittelyssä oli sekä kasvillinen että kasviton koejäsen. Koejäsenet olivat: 1. kasvillinen korkea (HWC), 2. kasviton korkea (HWB) ja 3. kasvillinen matala (LWC) pohjavesi. Koekäsittelyt aloitettiin heinäkuussa 2008. Tammikuussa 2009 pohjavesi nostettiin koejäsenessä LWC monoliiteissa $30 \mathrm{~cm}$ syvyydelle, jotta voitaisiin estää maamonoliitin kuivumiskutistuminen ja tästä mahdollisesti johtuvat oikovirtaukset putken seinämiä pitkin kasvukautena 2009. Pohjavesi laskettiin koejäsenessä LWC jälleen $65 \mathrm{~cm}$ syvyyteen toukokuussa 2009, kun taas koejäsenessä HWC vesipinta pidettiin $20 \mathrm{~cm}$ maan pinnan alapuolella koko kasvukauden. Lysimetrejä kasteltiin 10 kertaa kuussa keskimääräistä kuukausisadantaa vastaavilla vesimäärillä.

Koekäsittelyjen vaikutusta maan redox-potentiaaliin seurattiin jatkuvatoimisesti lysimetreihin viidelle eri syvyydelle $(10,30,50,70$ ja $90 \mathrm{~cm}$ ) asennettujen Pt-antureiden avulla, jotka luettiin dataloggerin avulla. Mitattu redox-potentiaalin arvo (referenssielektrodina $\mathrm{Ag} / \mathrm{AgCl}$ ) korjattiin laskennallisesti vastaamaan redoxpotentiaalia suhteessa normaalivetyelektrodiin $\left(E_{h}\right)$. Maan kosteus, lämpötila ja sähkönjohtavuus mitattiin 5TE-antureilla kolmesta eri syvyydestä $(10,30$ ja $70 \mathrm{~cm}) 10$ minuutin välein dataloggereilla. Huokosvesinäytteet kerättiin tyhjiökoeputkiin viiteen eri kerrokseen asennetuilla huokosvesikeräimillä. Näytteistä mitattiin pH ja sähkönjohtavuus. Huokosveden alkuainepitoisuudet analysoitiin induktiivisesti kytketyllä plasmaemissio-spektrometrillä (ICP-OES) ja orgaanisen hiilen kokonaispitoisuus määritettiin infrapunadetektorilla (TOC-V).

Dataloggereilla kerätyn aineiston tilastollinen käsittely tehtiin SURVO MM -tilasto-ohjelmalla. Manuaaliset mittaukset tallennettiin ja analysoitiin tilastollisesti Excel 2007 -ohjelmalla (t- testi).

\section{Tulokset}

Kokeen alussa kasvukautena 2008 redox-potentiaalin vaihtelu oli suurta kaikkien koejäsenten kerroksissa B ja BC. Korkean pohjaveden koejäsenessä B-kerrokset olivat ajoittain hapettuneita, koska pohjaveden pintaa ei pystytty pitämään halutussa korkeudessa päivittäisellä säätösäiliöiden täytöllä ruokohelven suuren transpiraation vuoksi (aineistoa ei ole esitetty tässä). Kasvukautena 2009 kerrokset B, BC ja C pysyivät veden kyllästäminä ja olivat pelkistyneitä koejäsenessä HWC (kuva 1). Koejäsenessä LWC kerrokset $\mathrm{BC}$ ja $\mathrm{C}$ olivat pelkistyneitä kasvukauden alussa ja BC muuttui hapettuneeksi kasvukauden aikana. Ajoittain myös C-kerroksessa mitattiin lyhytaikaisesti $300 \mathrm{mV}$ suurempia redox-potentiaalin arvoja. Koejäsenessä HWC maan vesipitoisuus $30 \mathrm{~cm}$ : n syvyydessä oli noin $0,5 \mathrm{~m}^{3} \mathrm{~m}^{-3}$ ja koejäsenessä LWC se laski arvoon $0,2 \mathrm{~m}^{3} \mathrm{~m}^{-3}$ kasvukauden 2009 aikana (kuva 1).

Ennen käsittelyjen aloittamista huokosveden pH oli kerroksissa B ja BC 3,6 - 4,3 ja C- kerroksessa 5,7 \pm 0,6. Matalan pohjaveden käsittelyn vaikutuksesta huokosvesi muuttui happamammaksi 50 ja $70 \mathrm{~cm}$ syvyydessä ( $\mathrm{pH} 3,7)$, kun taas korkean pohjaveden koejäsenessä huokosveden $\mathrm{pH}$ nousi $(\mathrm{pH} 4,5)$. Ckerroksen $\mathrm{pH}$ ei muuttunut tilastollisesti merkitsevästi kasvukauden 2009 aikana kummassakaan koejäsenessä. 

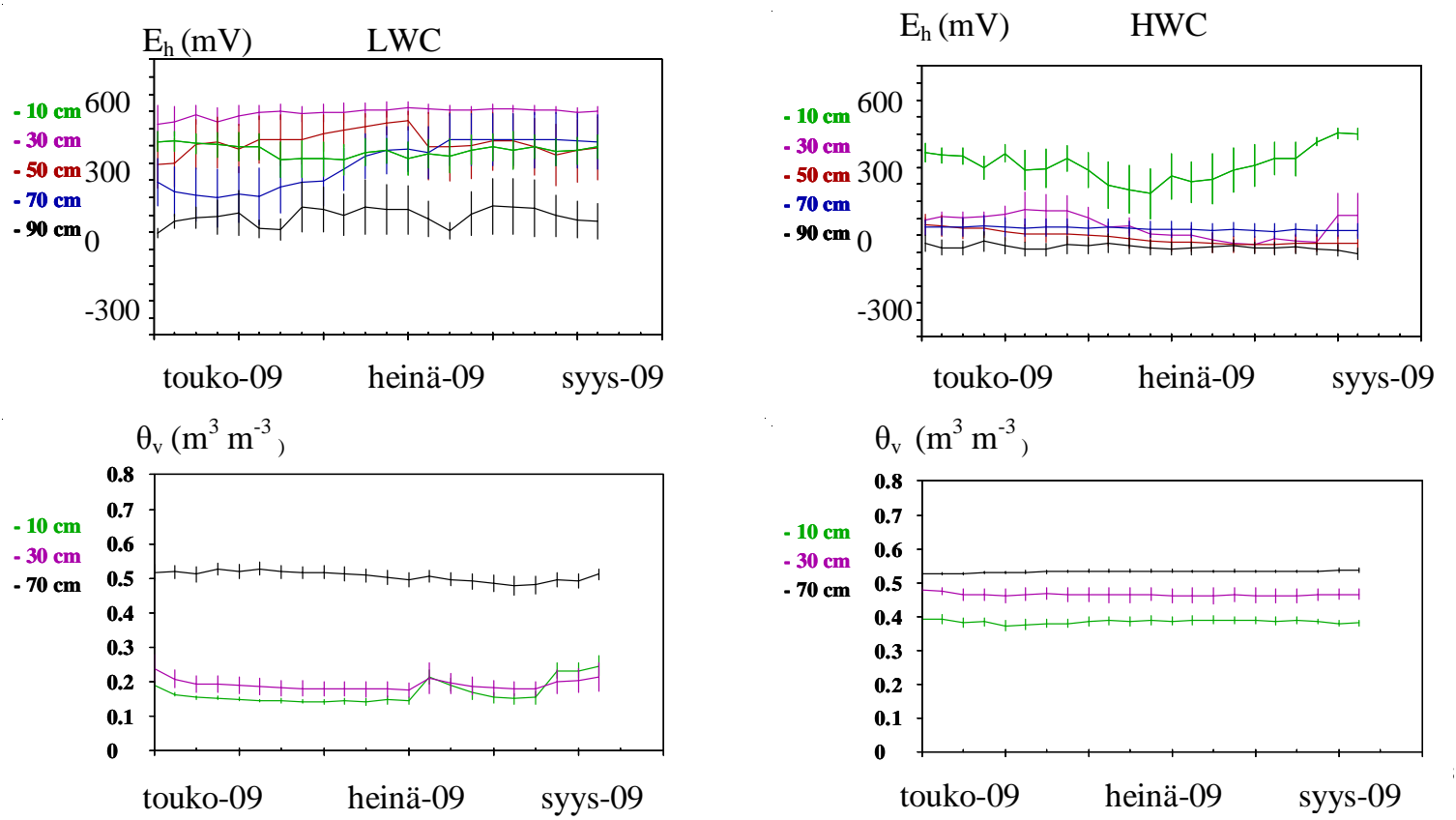

Kuva 1. Maan redox-potentiaali $\left(E_{\mathrm{h}} \mathrm{mV}\right) 10,30,50,70$ ja $90 \mathrm{~cm}$ syvyydessä ja kosteus $\left(\mathrm{m}^{3} \mathrm{~m}^{-3}\right) 10,30$ ja $70 \mathrm{~cm}$ syvyydessä kasvillisissa korkean (HWC) ja matalan (LWC) pohjaveden lysimetreissä 20.5.2009 - 31.9.2009.

Kokeen alussa suurimmat huokosveden sähkönjohtavuudet mitattiin C-kerroksesta (EC 2,4 $\pm 0,6 \mathrm{mS} \mathrm{cm}^{-1}$, keskiarvo \pm keskivirhe, $\mathrm{n}=10$ ). Kerroksissa $\mathrm{B}$ ja BC sähkönjohtavuus oli $1,1 \pm 0,5 \mathrm{mS} \mathrm{cm}^{-1} 50 \mathrm{~cm}$ ja $1,5 \pm$ $0,1 \mathrm{mScm}^{-1} 70 \mathrm{~cm}$ syvyydessä. Käsittelyjen vaikutuksesta huokosveden sähkönjohtavuus pieneni kasvillisessa maassa korkean pohjaveden käsittelyssä $\left(\mathrm{EC}_{70}=0,9 \pm 0,1 \mathrm{mS} \mathrm{cm}^{-1}, \mathrm{n}=4\right)$ ja kasvoi matalan pohjaveden käsittelyssä $70 \mathrm{~cm}$ syvyydessä $\left(\mathrm{EC}_{70}=1,5 \pm 0,2 \mathrm{mS} \mathrm{cm}^{1}, \mathrm{n}=4\right)$. Käsittelyjen välinen ero oli tilastollisesti merkitsevä $(\mathrm{P}<0,01)$.

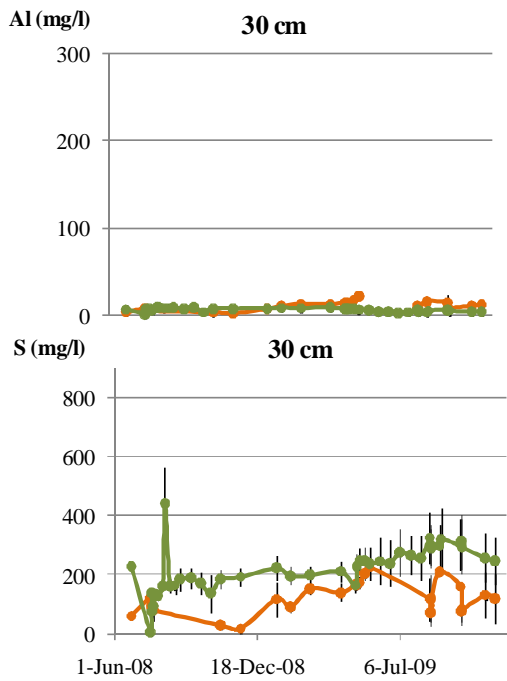

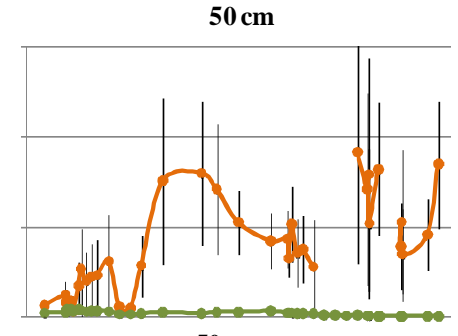

$50 \mathrm{~cm}$

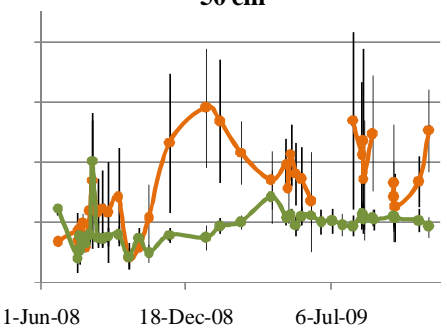

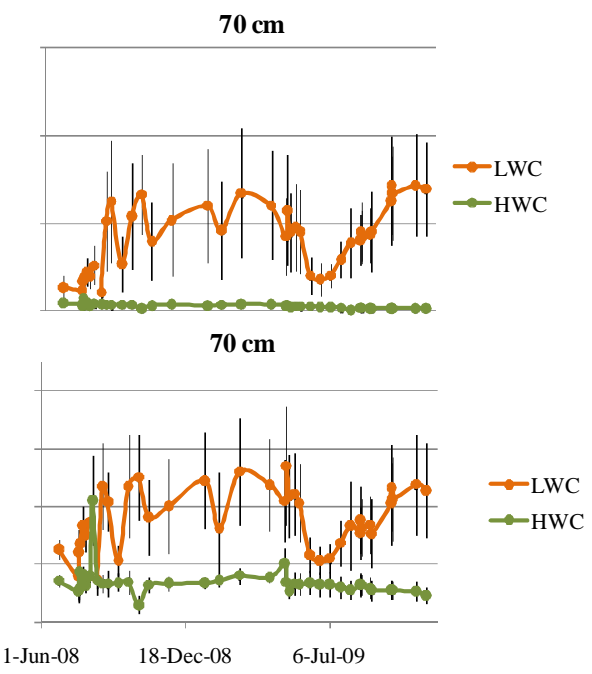

Kuva 2. Huokosveden rikin ja alumiinin pitoisuudet käsittelyssä HWC ja LWC ajanjaksolla 22.7.2008 -1.8.2009.

Matalan pohjaveden käsittelyssä (LWC) makerrosten hapettuminen nosti huokosveden rikin määrän pitoisuudesta 250 pitoisuuteen $500 \mathrm{mg} \mathrm{l}^{-1} \mathrm{BC}$-kerroksessa kesällä 2008. Keväällä 2009 pitoisuudet laskivat valunnan alkaessa. Lyhytaikainen hapettuminen kaksinkertaisti huokosveden rikin pitoisuudet C- 


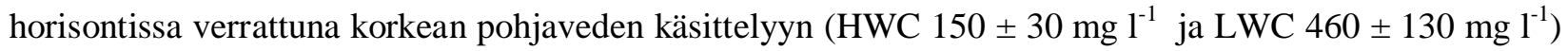
kesällä 2009. Kokeen alussa ero rikin pitoisuuksissa ei ollut tilastollisesti merkitsevä eri koejäsenten välillä, mutta kasvikauden lopussa oli. Alumiinin pitoisuudet olivat matalan pohjaveden käsittelyssä suurimmillaan $150 \mathrm{mg} \mathrm{l}^{-1} \mathrm{BC}$ - ja B-kerroksessa, kun korkean pohjaveden käsittelyssä pitoisuudet jäivät alle $10 \mathrm{mg} \mathrm{l}^{-1}$ kaikissa kerroksissa (kuva 2).

Korkean pohjaveden käsittelyssä pelkistyminen nosti huokosveden raudan pitoisuuksia kasvillisen koejäsen veden alle jääneissä kerroksissa. Matalan pohjaveden koejäsenessä (LWC) huokosveden raudan pitoisuus oli alle $1 \mathrm{mg} \mathrm{l}^{-1} 30 \mathrm{~cm}$ syvyydessä, kun se korkean pohjaveden koejäsenessä nousi samassa kerroksessa noin $450 \mathrm{mg} \mathrm{l}^{-1}$. Kasvittomassa koejäsenessä (HWB) huokosveden keskimääräinen raudan pitoisuus jäi alle $30 \mathrm{mg} \mathrm{l}^{-1}$ kaikissa kerroksissa. Koejäsenessä HWC huokosveden orgaanisen hiilen pitoisuudet kasvoivat $30 \mathrm{~cm}$ syvyydessä kasvukauden aikana alun pitoisuudesta $10 \mathrm{mg} \mathrm{l}^{-1}$ lopun pitoisuuteen $90 \mathrm{mg} \mathrm{l}^{-1}$. Kasvittoman koejäsenen orgaanisen hiilen pitoisuudet huokosvedessä olivat 2 - 20 $\mathrm{mg} \mathrm{l}^{-1}$ kasvukauden aikana. Kasvillisessa koejäsenessä maa oli pelkistynyttä $(\mathrm{Eh}<300 \mathrm{mV})$ veden alla pysyvästi olleissa kerroksissa. Vedellä kyllästymisen seurauksena $50 \mathrm{~cm}$ syvyydessä kasvittoman koejäsenen maa pelkistyi vähemmän kuin kasvillisen (kuva 3). Korkean pohjaveden käsittelyssä mitattu orgaanisen hiilen pitoisuus $90 \mathrm{mg} \mathrm{l}^{-1}$ on hehtaarille laskettuna $90 \mathrm{~kg} \mathrm{ha}^{-1} 20 \mathrm{~cm}$ paksuisessa maakerroksessa.

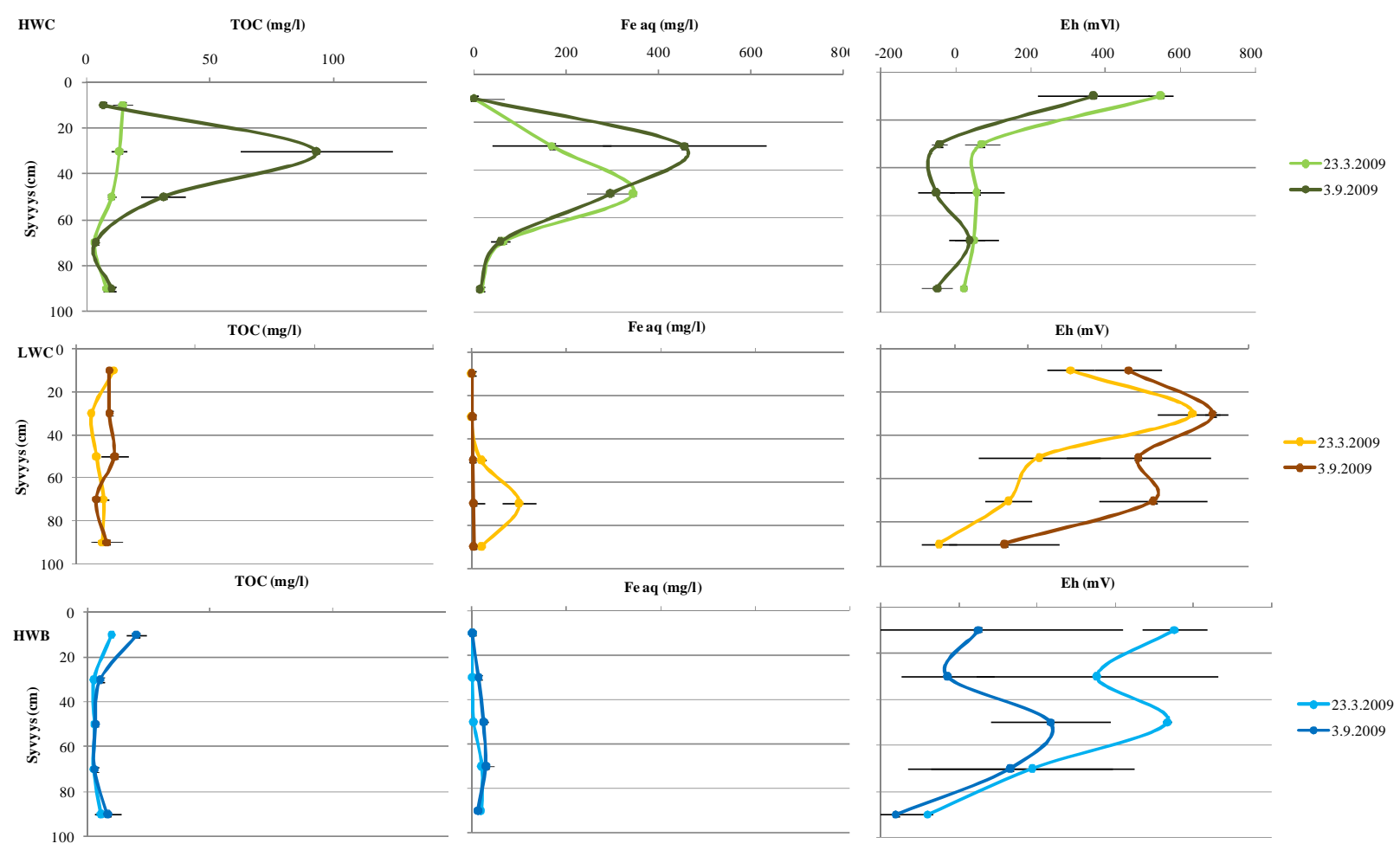

Kuva 3. Huokosveden orgaanisen hiilen ja raudan kokonaispitoisuudet sekä maan redox-potentiaali lysimetrien eri kerroksissa kasvillisissa koejäsenissä , joissa pohjavettä pidettiin korkealla (HWC) tai matalalla (LWC), sekä kasvittomassa koejäsenessä, jossa pohjavettä pidettiin korkealla (HWB).

Pohjaveden korkeus vaikutti huokosveden ionikoostumukseen. Rikkiä oli runsaasti kaikissa kerroksissa. Koekäsittelyn aikana koejäsenessä LWC alumiinin osuus nousi alun 2-3 \% :sta $14 \%$ :iin. Korkean pohjaveden käsittelyssä alumiinin määrä väheni prosenttiin tai sen alle. Korkean pohjaveden koejäsenessä raudan määrä kohosi $50 \mathrm{~cm}: n$ syvyydessä nollasta $46 \%$ :iin ja $70 \mathrm{~cm}: n$ syvyydessä yhdestä prosentista 18 \%:iin. Emäskationien ( $\mathrm{Ca}, \mathrm{K}, \mathrm{Mg}$ ja $\mathrm{Na}$ ) osuus huokosveden alkuaineista väheni kummassakin 
käsittelyssä alkutilanteen yli $50 \%$ :sta alle neljännekseen $50 \mathrm{~cm}$ syvyydessä. Emäskationien osuus pieneni 70 cm syvyydessä vähemmän koejäsenessä HWC kuin koejäsenessä LWC. Raskasmetalleista Ni-, Co- ja Zn-pitoisuudet kasvoivat $70 \mathrm{~cm}$ syvyydessä koejäsenessä HWC ennen käsittelyn aloittamista mitatuista pitoisuuksista ( $\left(\mathrm{WC}: \mathrm{Zn}=1,2 \mathrm{mg} \mathrm{l}^{-1}, \mathrm{Ni}=0,4 \mathrm{mg} \mathrm{l}^{-1}, \mathrm{Co}=0,2 \mathrm{mg} \mathrm{l}^{-1}\right.$ ). Korkean pohjaveden käsittelyssä pitoisuudet eivät muuttuneet käsittelyn seurauksena (HWC: $\mathrm{Zn}=0,5 \mathrm{mg} \mathrm{l}^{-1}, \mathrm{Ni}=0,1 \mathrm{mg} \mathrm{l}^{-1}, \mathrm{Co}=0,03 \mathrm{mg}$ $\left.1^{-1}\right)$. Muiden raskasmetallien pitoisuudet eivät muuttuneet tilastollisesti merkitsevästi käsittelyjen vaikutuksesta tai niiden pitoisuudet olivat alle määritysrajan $(0,01 \mathrm{mg} / \mathrm{l})$.
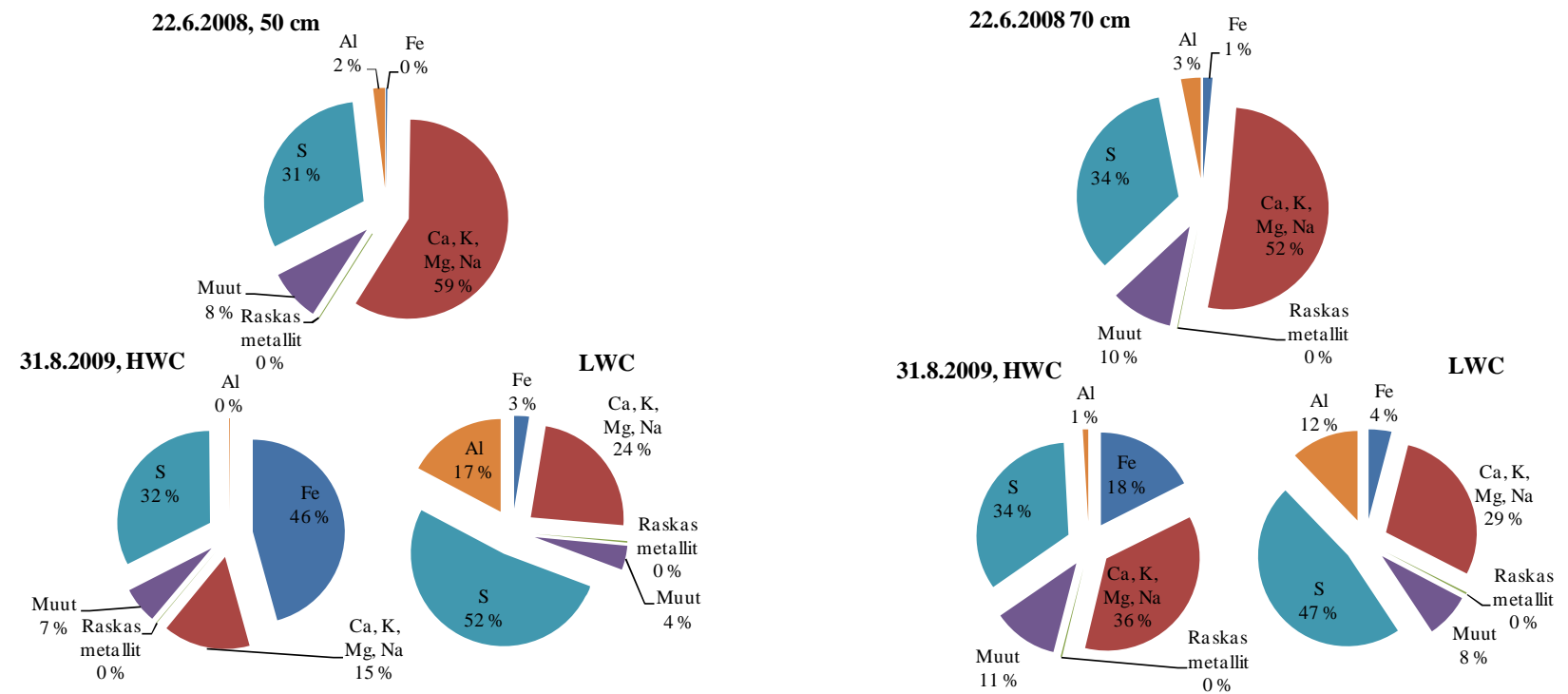

Kuva 4. Huokosveden ionikoostumus 50 ja $70 \mathrm{~cm}$ syvyyksissä ennen käsittelyjen aloittamista 25.6.2009, sekä koejäsenissä HWC ja LWC 31.8.2009, kun käsittelyt olivat kestäneet yhden vuoden.

Huokosveden kationien ja anionien varausten määrä laskettiin koejäsenten eri kerroksille ja summia verrattiin keskenään. Huokosveteen liuennut rikki oletettiin sulfaatiksi. Kokeen alussa kationien varausten määrä $\left(17 \mathrm{mmol}_{\mathrm{c}} \mathrm{l}^{-1}\right)$ oli anionien varausten määrää $\left(10 \mathrm{mmol}_{\mathrm{c}} \mathrm{l}^{-1}\right)$ suurempi C-kerroksessa. Koska maa on vanhaa merenpohjaa, huokosvedessä oli todennäköisesti myös kloori-ioneja, joita ICP-OES:llä ei voitu mitata. Kun anionien varausten määrään lisättiin natriumioneja vastaava määrä varauksia, saatiin kationien ja anionien varausten summa yhtä suureksi. Käsittelyjen vaikutuksesta matalan pohjaveden koejäsenessä ero kationien ja anionien varausten summassa poistui, mutta korkean pohjaveden koejäsenessä se oli alun kaltainen. Hapettuneissa kerroksissa, joista kloori oli todennäköisesti jo huuhtoutunut pois, olivat anionien ja kationien varausten määrät yhtä suuret. Kationien ja anionien varausten summien erotus kasvoi $30 \mathrm{~cm}$ syvyydessä korkean pohjaveden käsittelyssä, kun huokosveden raudan pitoisuudet kasvoivat kesällä 2009. Tällöin kationien varausten kokonaismäärä ylitti anionien varausten määrän suurimmillaan

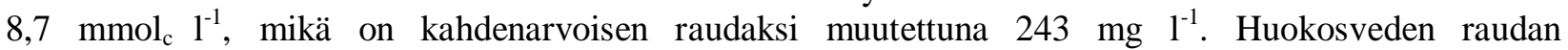
kokonaispitoisuudeksi mitattiin tällöin $450 \mathrm{mg} \mathrm{l}^{-1}$. Arvioitiin, että ionimuotoista rautaa olisi $207 \mathrm{mg} \mathrm{l}^{-1} \mathrm{ja}$ orgaaniseen ainekseen sitoutunutta rautaa olisi $243 \mathrm{mg}^{-1}$.

\section{Johtopäätökset}

Pohjaveden korkeuden nostaminen pelkisti hapettuneita sulfaattimaakerroksia kasvillisissa lysimetreissä jatkuvasti kyllästyneinä olleissa kerroksissa, joissa redox-potentiaali pysyi alle $300 \mathrm{mV}$. Odotetusti Ckerros pysyi pelkistyneenä koko kokeen ajan koejäsenissä HWC ja HWB. Matalan pohjaveden koejäsenen C-kerroksessa mitattiin ajoittain $300 \mathrm{mV}$ suurempia redox-potentiaalin arvoja, kun kerrokseen pääsi ilmeisesti juurien vedenoton seurauksena happea ja siinä olevat sulfidit alkoivat hapettua. Tämä aiheutti huokosveden rikin pitoisuuden kasvun sekä BC- että C-kerroksessa. Happamien olojen säilyminen ja sulfidien hapettumisen aiheuttama protonien lisääntyminen lisäsivät huokosveden alumiinipitoisuuksia ja 
niiden keskimääräiset pitoisuudet olivat kerroksissa B ja BC (150 mg $\left.\mathrm{l}^{-1}\right)$. Kun huokosissa oleva vesi huuhtoutuu salaojiin, tapahtuu laimenemista ja siksi salaojavedestä mitatut pitoisuudet ovat yleensä huokosveden pitoisuuksia pienempiä. Suomessa happaman sulfaattimaan salaojavesistä on mitattu korkeita alumiinipitoisuuksia (25 - $90 \mathrm{mg} \mathrm{l}^{-1}$ ) (Bärlund 2004). Jos laimeneminen on tätä suuruusluokkaa, voidaan arvioida, että korkean pohjaveden koejäsenessä, jossa huokosveden alumiinipitoisuudet eivät ylittäneet $10 \mathrm{mg} \mathrm{l}^{-1}$, salaojaveden alumiinipitoisuudet olisivat 1,3-6 mg $\mathrm{l}^{-1}$. Koska alumiinin on todettu olevan vesieliöille ja kaloille haitallinen pitoisuuksien ollessa $0,1-2 \mathrm{mg} \mathrm{l}^{-1}$ (Vuori 2008), voivat pitoisuudet tässäkin tapauksessa olla haitallisia. Matalan pohjaveden koejäsenessä huokosveden sinkin, nikkelin ja koboltin pitoisuudet kasvoivat kokeen kuluessa BC-kerroksessa. Korkean pohjaveden koejäsenessä pitoisuudet eivät muuttuneet alkutilan pitoisuuksista käsittelyn vaikutuksesta. Matalan pohjaveden koejäsenen huokosvedestä mitatut pitoisuudet olivat yli viisinkertaisia happamien sulfaattimaiden jokivesistä mitattuihin pitoisuuksiin verrattuna (Nordmyr 2008).

Korkean pohjaveden kasvillisessa koejäsenessä huokosveden raudan pitoisuus nousi suureksi (450 mg $\left.\mathrm{l}^{-1}\right)$. Vastaavaa raudan pitoisuuksien lisääntymistä ei havaittu kasvittomassa korkean pohjaveden koejäsenessä. Huokosveden suureen raudan määrään lienee syynä mikrobien katalysoima rautahydroksidien pelkistyminen ja orgaanisten rautayhdisteiden muodostuminen. Vastaionien perusteella laskettiin, että huokosveden raudasta oli orgaaniseen ainekseen sitoutunutta varauksetonta rautaa yli $50 \%$. Vastaavanlainen raudan suhteen ylikylläinen tilanne on havaittu tulvitetuilla riisiviljelmillä (Ponnamperuma 1985). Vaikka rautahydroksidien pelkistymistä tapahtui korkean pohjaveden käsittelyssä, ei huokosveden $\mathrm{pH}$ noussut neutraaliksi. Tähän lienee eräänä syynä mikrobien hengityksessä vapautunut hiilidioksidi, joka puskuroi rautahydroksidien pelkistymisessä vapautuvien $\mathrm{OH}^{-}$-ionien aiheuttaman emäslisäyksen. Korkean pohjaveden käsittelyssä huokosveden orgaanisen hiilen suuri määrä oli todennäköisesti ruokohelven juuriston tuottamaa helposti hajoavaa orgaanista ainetta.

Kokeen tähänastiset tulokset tukevat hypoteesia korkean pohjaveden alumiinipitoisuuksia vähentävästä vaikutuksesta huokosvedessä lysimetrin B- ja BC-kerroksessa ja raskasmetallipitoisuuksia vähentävästä vaikutuksesta $\mathrm{BC}$-kerroksessa, vaikka huokosveden happamuus väheni vain noin yhden $\mathrm{pH}$-yksikön verran korkean pohjaveden vaikutuksesta.

\section{Kirjallisuus}

Bärlund, I., Tattari, S., Yli-Halla, M. \& Åström, M. 2004. Effects of sophisticated drainage techniques on groundwater level and drainage water quality on acid sulphate soils -Final report ot the HAPSU project, The Finnish Environment 732, $68 \mathrm{~s}$.

Kirk, G. 2004. The biogeochemistry of submerged soils. Wiley, Chichester. viii, $291 \mathrm{s.}$

Nordmyr, L., Österholm, P. \& Åström, M. 2008. Estuarine behaviour of metal loads leached from coastal lowland acid sulphate soils. Marine Environmental Research 66(3): 378-393.

Ponnamperuma, F. N. 1985 Chemical kinetics of wetland rice soils relative to soil fertility. p. 71-89, In: Wetland soils:characterization, classification and utilization. IRRI, Manila, Philippines.

Rautio, L-M. 2008, Maaperän happamuus vesien hoidon suunnittelussa, Vesitalous, 4 s. 16-18.

Vuori, K-M. 2008. Alumiini jokivesistössä, http://www.ymparisto.fi/default.asp?contentid=109744\&lan=fi

Yli-Halla, M., Mokma, D. L., Wilding, L. P. \& Drees, L. R. 2008. Morphology, Genesis and Classification of Acid Sulfate Soils of Finland. p. 224-228.

Österholm, P., Åström, M. 2004 Quantification of current and future leaching of sulfur and metals from Boreal acid sulfate soils, western Finland. Australian Journal of Soil Research 42: 547-551. 